\title{
The Use of Cloned nif Regulatory Elements from Klebsiella pneumoniae to Examine nif Regulation in Azotobacter vinelandii
}

\author{
By CHRISTINA KENNEDY* AND MARTIN H. DRUMMOND \\ AFRC Unit of Nitrogen Fixation, University of Sussex, Brighton BN1 9RQ, UK
}

(Received 28 November 1984; revised 5 March 1985)

\begin{abstract}
Regulatory genes controlling nif expression and also nif promoters fused to lacZ from Klebsiella pneumoniae were cloned on wide-host-range plasmids and introduced into Azotobacter vinelandii to compare regulation of nif expression in the two organisms. A low-copy-number plasmid carrying $K$. pneumoniae nif $A$ corrected an $A$. vinelandii $\mathrm{Nif}^{-}$regulatory mutation, whereas a plasmid carrying $n t r C$ did not. A high-copy-number plasmid carrying $K$. pneumoniae nif $L$ eliminated nif expression in $K$. pneumoniae but not in $A$. vinelandii. $K$. pneumoniae nif $L$ - and nif $F$-lac $Z$ fusions were expressed strongly in $A$. vinelandii and were not repressed by ammonium. A nif $H-l a c Z$ fusion was not expressed in any conditions in this background except very weakly when $K$. pneumoniae nif $A$ was also present. The implications of these findings are discussed.
\end{abstract}

\section{INTRODUCTION}

The genetics of $\mathrm{N}_{2}$ fixation has been analysed in greater detail in Klebsiella pneumoniae than in any other diazotroph, owing to the close relationship of this organism to Escherichia coli. The resulting model of nif gene structure, function and regulation has been referred to extensively in analyses of $\mathrm{N}_{2}$ fixation in other species, and the availability of cloned nif genes from $K$. pneumoniae has been exploited to great advantage in comparative studies. Here we use this approach to explore the functional similarities between control of nif expression in the facultative anaerobe $K$. pneumoniae and in the obligate aerobe Azotobacter vinelandii.

The nif $L A$ operon, within the 17 gene nif cluster of Klebsiella, encodes two regulatory proteins (Roberts \& Brill, 1980; Kennedy et al., 1981). The nifA product is an activator which is essential for full expression of each nif promoter except that of its own operon (Dixon et al., 1980; Buchanan-Wollaston et al., 1981 a). The nif $L$ product represses nif expression in response to oxygen, certain amino acids and low levels of ammonia (Hill et al., 1981; Merrick et al., 1982; Filser $e t$ al., 1983) and appears to directly inactivate the nif $A$ product, rather than itself binding to DNA (Buchanan-Wollaston \& Cannon, 1984; Drummond \& Kennedy, 1984). Transcription from the nif $L A$ promoter is normally activated by the $n t r C$ product which also controls the expression of other genes involved in the utilization of poor nitrogen sources such as arginine, proline and histidine (Drummond et al., 1983; Merrick, 1983; Ow \& Ausubel, 1983). nif A and $n t r C$ show numerous similarities, including a common dependence on the $n t r A$ product for their activity (Merrick, 1983; Ow \& Ausubel, 1983). At high levels of ammonium, $n t r C$ activation of the nifLA promoter is eliminated. Thus nif expression in Klebsiella is regulated at two levels, one general and one nif-specific.

The Klebsiella nif promoters have a structure unlike other promoters analysed in the enteric bacteria, and contain the consensus sequence CTGG- $\mathrm{N}_{8}-\mathrm{TTGCA}$ instead of the usual -10 and -35 consensus sequences (Beynon et al., 1983). The recognition properties of RNA polymerase must be specifically altered for these nif promoters, and it has been suggested that one of the proteins involved in activation, perhaps the ntrA product, is substituted for conventional sigma factor as a regulatory switch (de Bruijn \& Ausubel, 1983). Promoters normally activated by $n t r C$ in the enteric bacteria closely resemble the nif consensus promoter and can be activated to some extent by nif $A$ (Ow et al., 1983; Merrick, 1983; Ow \& Ausubel, 
1983). The converse, however, is not invariably true; in particular, the nif $H$ promoter from $K$. pneumoniae is not positively regulated by $n \operatorname{trC}$ (Ow et al., 1983), although that from Rhizobium meliloti can be activated by either nif $A$ or $n \operatorname{tr} C$ (Sundaresan et al., 1983a,b).

Nucleic acid hybridization experiments and DNA sequence analysis show that nif genes are highly conserved between distantly related species (for examples see Ruvkun \& Ausubel, 1980; Hase et al., 1984). Such observations, in conjunction with the apparently random occurrence of diazotrophy within genera, suggest that modern diazotrophs have acquired their nif genes rather recently in evolutionary history (see Postgate, 1982). If so, one would suspect strong hybridization between DNA sequences immediately associated with nitrogenase function, but not necessarily between regulatory genes, since these are responsible for integrating the nif regulon into quite different metabolic backgrounds. This appears to hold for $K$. pneumoniae and Azotobacter chroococcum where hybridization was observed between the nif $K D H$ and $V$ genes of these two organisms but not between the nifLA genes (Jones et al., 1984). However, in $R$. meliloti a region of DNA linked to the nif $H D K$ operon hybridizes to $K$. pneumoniae $n t r C$ and nif $A$ DNA, and inserts of $\operatorname{Tn} 5$ in this region confer a regulatory $\mathrm{Fix}^{-}$phenotype (Szeto et al., 1984).

To investigate possible intergeneric homology at the functional level, we have introduced certain Klebsiella regulatory genes into $A$. vinelandii on wide-host-range plasmids and observed the effect on nif expression. We have also used Klebsiella nif promoters fused to lacZ on widehost-range plasmids as probes for Azotobacter regulatory proteins functionally analogous to those in Klebsiella. Our findings suggest that the nif regulatory mechanism in Azotobacter includes an $n t r C$-like activator, but that nif-specific regulation is less like that of $K$. pneumoniae than was suggested by the earlier observation that the Klebsiella nif $A$ product activates nif expression in $A$. chroococcum and $A$. vinelandii (Kennedy \& Robson, 1983). These results may also explain why pRD1, which carries the entire Klebsiella nif cluster, fails to confer a $\mathrm{Nif}^{+}$ phenotype on $A$. vinelandii strains with mutations in the structural genes for nitrogenase (Cannon \& Postgate, 1983).

\section{METHODS}

Bacteria. The strains used in this work are described in Table 1.

Plasmid construction. The plasmids used to construct various other recombinant plasmids are described in Table 2. Restriction enzymes, Bal31, T4 DNA ligase and polymerase were obtained from commercial sources and used

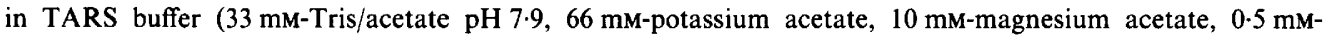
dithiothreitol, $4 \mathrm{mM}$-spermidine, $10 \mu \mathrm{g}$ pancreatic RNAase $\mathrm{ml}^{-1}$ ) following standard procedures (Maniatis $e t$ al., 1982). To make pMD114, a set of deletions was made in pMM12 (Espin et al., 1982) by using Bal31 as an endonuclease on supercoiled DNA, followed by restriction, generation of blunt ends, and intra-molecular ligation. The structure of the recombinant plasmids was ascertained by restriction analysis of small scale DNA preparations (Holmes \& Quigley, 1981).

Media. Burk's medium with $1 \%$ sucrose (BS; Newton et al., 1953) was used for growing A. vinelandii; LA was used as rich medium and NFDM as nitrogen-free medium for growing E. coli and K. pneumoniae (Kennedy, 1977; Dixon et al., 1977). Ammonium acetate $\left(1.1 \mathrm{mg} \mathrm{ml}^{-1}\right)$ was added as nitrogen source. UWr and UW1r resisted rifampicin $\left(25 \mu \mathrm{g} \mathrm{ml}^{-1}\right)$. Antibiotics were added for $E$. coli (and $K$. pneumoniae) and for $A$. vinelandii, respectively, as follows: streptomycin, 50 and $1 \mu \mathrm{g} \mathrm{ml}^{-1}$; ampicillin, 50 and $15 \mu \mathrm{g} \mathrm{ml}^{-1}$; kanamycin, 40 and $1 \mu \mathrm{g} \mathrm{ml}^{-1}$; tetracycline, 10 and $2 \mu \mathrm{g} \mathrm{ml}^{-1}$; sulfathioazole, $200 \mu \mathrm{g} \mathrm{ml}^{-1}$ for both organisms. X-Gal (5-bromo-4-chloro-3-indolyl $\beta$-D-galactopyranoside) was added to BS solid medium at $30 \mu \mathrm{g} \mathrm{ml}^{-1}$.

Plasmid transfer. The $\mathrm{Tra}^{+}$mobilizing plasmid pRK2013 (Figurski \& Helinski, 1979) was used to mobilize other plasmids between $E$. coli strains or between $E$. coli and strains of Azotobacter. Tri-parental matings were done by mixing $25 \mu$ l exponential phase cultures on LB agar plates (Dixon et al., 1977) (for transfer to $E$. coli) or on Burk's sucrose agar supplemented with $25 \%(\mathrm{w} / \mathrm{v}) \mathrm{LB}$ agar, $0.2 \%$ glucose and $15 \mathrm{mM}$-ammonium acetate (for transfer to A. vinelandii or to $A$. chroococcum). Plates used for matings were incubated for $18 \mathrm{~h}$ at $30^{\circ} \mathrm{C}$ after which the cells were scraped from the plates, resuspended in buffer and plated on selective medium. The various recombinant IncQ and IncP plasmids (Table 2) transferred to $A$. vinelandii at frequencies of $10^{-1}-10^{-2}$ per recipient. Only pMD23 could be transferred to $A$. chroococcum MCD-1, and at a frequency of about $10^{-5}$. Since MCD-1 is resistant to streptomycin, there was no means of selecting for transfer of pMD61 to this strain. We were unable to transfer the IncP plasmid pCK 3 to MCD-1 or its derivatives (see Table 1 and Robson et al., 1984).

Although pRK2013 failed to replicate in $A$. vinelandii, it apparently could be transferred and transiently expressed to allow mobilization of plasmids to $E$. coli. Transfer frequency of pMD61 from $A$. vinelandii UWr to HB101 after mixing these two cultures with JC5466(pRK2013) was about $10^{-4}$ to $10^{-5}$ per recipient. Similar 


\section{Table 1. Bacterial strains}

\begin{tabular}{|c|c|c|}
\hline Species & Strain no. & Relevant genotype/phenotype \\
\hline pneumoniae & $\begin{array}{l}\text { UNF931 } \\
\text { UNF745 }\end{array}$ & $\begin{array}{l}\text { hisD2 recA56 srl-300::Tnlo hsdRI } \\
\Delta(\text { lac }) 2002 \\
\text { nifA } 2787:: \operatorname{Mud}\left(\mathrm{Ap}^{\mathrm{r} l a c}\right) \text { recA56 } \\
\text { srl-300::Tn } 10 \text { hsdRI } \Delta(\text { lac }) 2002 \mathrm{Gal}\end{array}$ \\
\hline coli & $\begin{array}{l}\text { ET } 8556 \\
\text { HB101 } \\
\text { JC5466 }\end{array}$ & $\begin{array}{l}\text { ntrC1488 lacZ: : ISI gyrA hutC } \mathrm{C}_{\mathrm{K}}^{\mathrm{Rbs}} \mathrm{Rb}^{-} \\
\text {hsdS recA13 proA lacY galK rpsL } \\
\text { supE Xyl } \mathrm{Xtl}^{-} \mathrm{Ara}^{-} \\
\text {trp recA56 rpsE } \mathrm{His}^{-}\end{array}$ \\
\hline 4. vinelandii & $\begin{array}{l}\text { UWr } \\
\text { UW1r } \\
\text { UW2r }\end{array}$ & $\begin{array}{l}\text { Nif }{ }^{+} \mathrm{Rif}^{\mathrm{r}} \\
\text { nifl } \mathrm{Rif}^{\mathrm{r}} \\
\text { nif2 } 2 \mathrm{Rif}^{\mathrm{r}}\end{array}$ \\
\hline chroococcum & $\begin{array}{l}\text { MCD-1 } \\
\text { MCD-1008 }\end{array}$ & $\begin{array}{l}\mathrm{Nif}^{+} \\
\text {Nif }^{-}\end{array}$ \\
\hline
\end{tabular}

Source or reference

Drummond et al. (1983)

Merrick et al. (1982)

MacNeil et al. (1982)

P. Nurse, ICRF, London, UK

R. Dixon, AFRC Unit of Nitrogen Fixation, Sussex, UK

Bishop \& Brill (1977)

Shah et al. (1973)

Gordon \& Brill (1972)

Robson et al. (1984)

Kennedy \& Robson (1983)

Table 2. Plasmid construction

\begin{tabular}{|c|c|c|c|c|c|c|}
\hline Designation & pMD21 & pMD23 & pMD61 & pMD45 & pMD132 & pCK3 \\
\hline $\begin{array}{l}\text { Promoter fusion or } \\
\text { regulatory gene }\end{array}$ & nifF-lac $Z$ & nifL-lacZ & nifH-lacZ & $n t r C$ & $n i f L$ & $n i f A$ \\
\hline Parent replicons* & $\begin{array}{l}\text { RSF1010, } \\
\text { pRD543 }\end{array}$ & $\begin{array}{l}\text { RSF1010, } \\
\text { pRD512 }\end{array}$ & $\begin{array}{l}\text { RSF1010, } \\
\text { pJB31 }\end{array}$ & $\begin{array}{l}\text { RSF1010, } \\
\text { pMD114 }\end{array}$ & $\begin{array}{l}\text { RSF1010, } \\
\text { pMD2 }\end{array}$ & $\begin{array}{l}\text { pRK290, } \\
\text { pMC73A }\end{array}$ \\
\hline Incompat & IncQ & IncQ & IncQ & IncQ & IncQ & IncP \\
\hline Site of co & $E c o$ RI & EcoRI & PstI & PstI & EcoRI & BglII/BamHI \\
\hline Size & $19.0 \mathrm{~kb}$ & $19 \cdot 6 \mathrm{~kb}$ & $19.0 \mathrm{~kb}$ & $14.8 \mathrm{~kb}$ & $14.9 \mathrm{~kb}$ & $27 \mathrm{~kb}$ \\
\hline Drug resistances & $\mathrm{Ap}^{r} \mathrm{Su}^{\mathrm{r}}$ & $\begin{array}{l}\mathrm{Ap}^{\mathrm{r}} \mathrm{Su}^{\mathrm{r}} \\
\text { nif } F-\mathrm{Sm}^{\mathrm{r}}\end{array}$ & $\mathrm{Sm}^{\mathrm{r}}$ & $\mathrm{Sm}^{\mathrm{r}}$ & $\begin{array}{l}\mathrm{Ap}^{\mathrm{r}} \mathrm{Su}^{\mathrm{r}} \\
\text { nifF-Sm }\end{array}$ & $\begin{array}{l}\mathrm{Tc}^{r} \\
\text { nif } B-\mathrm{Km}^{\mathrm{r}}\end{array}$ \\
\hline
\end{tabular}

* References are as follows: RSF1010, Guerry et al. (1974); pRD543 and pRD512, Drummond et al. (1983); pJB31 and pMC73A, Buchanan-Wollaston et al. (1981 a); pMD114 and pMD2, this paper; pRK290, Ditta et al. (1980). Plasmid pRD512 is analogous to pRD526 (Drummond et al., 1983), except that the fusion junction is at codon 98 of nifL rather than codon 33 .

frequencies were obtained for transfer of other IncQ plasmids from $A$. vinelandii, but $\mathrm{pCK} 3$, an IncP plasmid, could not be mobilized from UW $1 \mathrm{r}$ using pRK2013. Also, the presence of pCK 3 inhibited transfer of pMD61 from UWr; transfer of pMD61 to HB101 from UWr(pMD61) (pCK3) was reduced by about 100-fold.

Enzyme assays. Cultures for measuring nitrogenase and/or $\beta$-galactosidase activities were prepared by first suspending organisms taken from 1-d-old selective agar plates in $\mathrm{NH}_{4}^{+}$-containing NFDM (for $K$. pneumoniae) or Burk's sucrose (for $A$. vinelandii) with appropriate antibiotics for plasmid selection. These liquid culture were grown with shaking for 6-8 $\mathrm{h}$ to a density of about $10^{9}$ cells ml-1, and were then centrifuged, resuspended and diluted $10^{-1}$ as follows: $K$. pneumoniae into $5 \mathrm{ml} \mathrm{NFDM}$ with and without added $\mathrm{NH}_{4}^{+}(15 \mathrm{mM})$ in $7 \mathrm{ml}$ bijou bottles closed with a suba-seal; $A$. vinelandii into $5 \mathrm{ml}$ Burk's sucrose with and without added $\mathrm{NH}_{4}^{+}(15 \mathrm{mM})$ in $25 \mathrm{ml}$ cotton-stoppered flasks. $\mathrm{NH}_{4}^{+}$-free cultures of the $\mathrm{Nif}^{-}$mutant $\mathrm{UW} / \mathrm{r}$ contained urea $(2 \mathrm{mM})$ as a non-repressing nitrogen source. Culture vessels were incubated with shaking for $16 \mathrm{~h}$ at $30^{\circ} \mathrm{C}$. Acetylene reduction was measured for K. pneumoniae $15 \mathrm{~min}$ after injecting $0.5 \mathrm{ml}$ acetylene directly into the closed bijou bottles. A sample $(1 \mathrm{ml})$ of each $A$. vinelandii culture was transferred to a $7 \mathrm{ml}$ bijou bottle for a similar $15 \mathrm{~min}$ assay. Two samples $(0 \cdot 1 \mathrm{ml})$ were removed from duplicate cultures for measuring $\beta$-galactosidase activity as described by Miller (1972).

\section{RESULTS}

\section{Plasmid construction}

Cointegrates were constructed in vitro between small plasmids carrying $K$. pneumoniae regulatory genes (nif $A$, ntrC and nifL) or nif-lac $Z$ fusions and the wide-host-range plasmids pRK290 (IncP; Ditta et al., 1980) or RSF1010 (IncQ; Guerry et al., 1974). Their properties and mode of construction are summarized in Table 2, and the physical structures of the IncQ derivatives, as confirmed by restriction analysis, are depicted in Fig. 1. Plasmid pCK3 is a cointegrate of pMC73A and pRK290 formed by ligation between the respective Bam $\mathrm{HI}$ and 


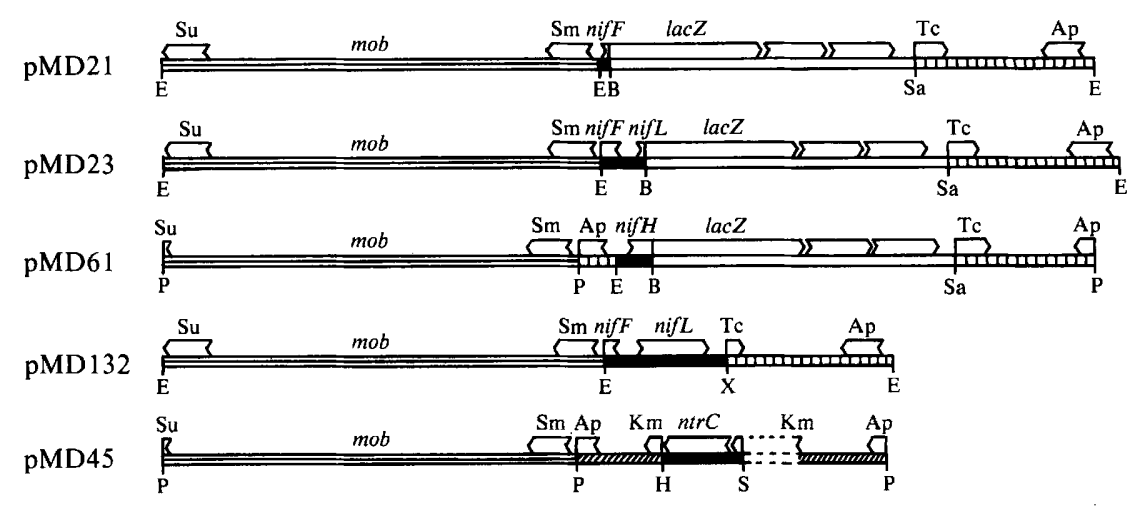

Fig. 1. Structure of IncQ plasmids carrying $K$. pneumoniae nif promoters and nif-lac fusions. Open boxes show the position and direction of transcription of structural genes. The dashed line in pMD45 designates sequences of unknown origin. Restriction sites: B, BamHI; E, Eco RI ; H, HindIII; P, Pst I; $\mathrm{S}, \mathrm{SmaI}$; Sa, SalI; X, XmaIII. Drug resistance genes: Ap, ampicillin; Sm, streptomycin; Su, sulphonamide; Tc, tetracycline. pneumoniae sequences; $\square$, lac sequences.

BglII sites. Rearrangements which occurred in the physical structure of this plasmid in vivo made it difficult to characterize fully by restriction analysis, but it retained all the relevant genetic markers of the component replicons, except for ampicillin resistance carried by pMC73A (Buchanan-Wollaston et al., 1981a). However, pCK3 did retain temperature-sensitive expression of the $\mathrm{Km}^{\mathrm{r}}$ gene which in pMC3A is translationally fused to the nifB promoter and hence under the control of the thermolabile nif $A$ activator (Kennedy \& Robson, 1983).

The remaining cointegrates were all made with the IncQ plasmid, RSF1010. The nif $L$ gene from K. pneumoniae was cloned into pBR322 on an EcoRI-XmaIII fragment to give pMD2, which was joined to RSF1010 at the EcoRI site to give pMD132. The $n t r C$ plasmid pMD114, used to make pMD45, was derived from pMM12 (Espin et al., 1982) using Bal 31 to delete $2.6 \mathrm{~kb}$ between the HindIII site in pACYC177 and the end of the regulatory gene, thereby removing IS 21 sequences present in this region. This was done in an attempt to stabilize the eventual cointegrate pMD45. The other small plasmids used in this study have all been described previously: pJB31, pMC73A, pRD512 and pRD543 used to make pMD61, pCK3, pMD23 and pMD21, respectively (see Table 2 for references).

During construction of these cointegrates we found that while pMD21, pMD23 and pMD132 were stable, similar constructs with the constituent replicons in the opposite orientation to that shown in Fig. 1 were not; the latter disintegrated in $E$. coli to give two plasmids indistinguishable in size from the parent plasmids. The reason for this instability is unclear.

Instability of a different kind was observed in pMD45. During prolonged growth with selection for streptomycin resistance in E. coli ET8556 $\left(\mathrm{NtrC}^{-}\right)$, the original construct was gradually replaced in the population by a derivative which had spontaneously acquired an additional 960 bp of extraneous DNA between the $\mathrm{Km}^{\mathrm{r}}$ promoter and the start of the $n t r C$ gene. Nevertheless, the plasmid remained $n t r C^{+}$in $E$. coli.

The copy numbers of these cointegrates were not measured precisely in either $K$. pneumoniae or $A$. vinelandii, but rough estimates were possible based on comparisons of plasmid yields in small-scale DNA preparations. In E. coli, RSF1010 and its derivatives are maintained at 20-50 copies per cell (Nagahari \& Sakaguchi, 1978) while IncP plasmids are present at about five copies per cell (Figurski et al., 1979). The staining intensities on agarose gels of supercoiled plasmid DNA prepared from saturated cultures of all three organisms were similar, suggesting 5- to 10-fold higher copy number of IncQ than IncP replicons, whether or not these were present in the same cell. A. vinelandii has about 40 chromosomes per cell (Sadoff et al., 1979) and therefore the plasmid to chromosome ratio is at least $2: 1$ for RSF1010 derivatives and $1: 5$ for the IncP plasmid pCK3. 
Table 3. Nitrogenase activities [nmol ethylene produced min $^{-1}$ ( $m$ g protein $)^{-1}$ ] in $K$. pneumoniae and $A$. vinelandii transconjugants

\begin{tabular}{|c|c|c|c|c|c|c|}
\hline \multirow[b]{3}{*}{ Plasmid } & \multirow{2}{*}{\multicolumn{2}{|c|}{$\begin{array}{l}\text { K. pneumoniae } \\
\text { UNF931* }\end{array}$}} & \multicolumn{4}{|c|}{ A. vinelandii ${ }^{*}$} \\
\hline & & & & & & \\
\hline & $-\mathrm{NH}_{4}^{+}$ & $+\mathrm{NH}_{4}^{+}$ & $-\mathrm{NH}_{4}^{+}$ & $+\mathrm{NH}_{4}^{+}$ & $-\mathrm{NH}_{4}^{+}$ & $+\mathrm{NH}_{4}^{+}$ \\
\hline None & $58(+)$ & 0 & $65(+)$ & 0 & $0(-)$ & ND \\
\hline pMD132 (nifL) & $0(-)$ & 0 & $61(+)$ & 0 & $0(-)$ & ND \\
\hline pCK3 (nifA) & $65(+) \dagger$ & $49 \dagger$ & $48(+)$ & 52 & $60(+)$ & 9 \\
\hline $\begin{array}{l}\text { pMD132+ pCK3 } \\
(\text { nifL }+ \text { nif } A)\end{array}$ & ND & ND & $63(+)$ & 0 & $2 \cdot 4(-)$ & ND \\
\hline pMD61 (nifH-lacZ) & $0(-)$ & 0 & $58(+)$ & ND & $0(-)$ & ND \\
\hline pMD23 (nifL-lacZ) & $55(+)$ & 0 & $55(+)$ & ND & $0(-)$ & ND \\
\hline pMD45 (ntrC) & $(+)$ & & $60(+)$ & 0 & $0(-)$ & 0 \\
\hline
\end{tabular}

ND, Not determined.

* $(-)$ or $(+)$ indicates extent of growth of transconjugant on nitrogen-free agar medium. $\dagger$ In nifL $A$ strain UNF745.

\section{Effect of $K$. pneumoniae regulatory genes on $N_{2}$ fixation in $A$. vinelandii}

The IncP nif $A$ plasmid pCK 3 corrected the $\mathrm{Nif}^{-}$phenotype in the $A$. vinelandii regulatory mutants UW1r (Table 3) and UW2r (not shown), restoring wild-type levels of nitrogenase activity. Like pCK 1, an IncQ nif $A$-constitutive plasmid (Kennedy \& Robson, 1983), pCK 3 also activated nif expression in ammonium-grown cultures of $\mathrm{UWl}$ r or $\mathrm{UWr}$, the $\mathrm{Nif}^{+}$parent strain. Its compatibility with the IncQ cointegrates described above made possible the construction of several useful $\boldsymbol{A}$. vinelandii transconjugants. A further advantage of pCK 3 over pCK 1 is that it did not inhibit growth of $A$. vinelandii, presumably a result of its lower copy number and hence lower dosage of the nif $A$ gene.

The multicopy nif $L$ plasmid, pMD132, completely repressed $\mathrm{N}_{2}$ fixation in $K$. pneumoniae, but not in $A$. vinelandii. The nif $L$ gene product did, however, prevent the nif $A$ product cloned in pCK 1 from restoring a $\mathrm{Nif}^{+}$phenotype in the regulatory mutant UW1r (Table 3); nitrogenase activity in UW1r(pCK3)(pMD132) was only about $4 \%$ of that of UW1r(pCK3). A control experiment showed that the IncQ vector RSF1010, used to make pMD132, had no effect on activation of UW1r by pCK3 (data not shown).

To see whether multiple copies of the $K$. pneumoniae nif $H$ promoter would inhibit $\mathrm{N}_{2}$ fixation in $A$. vinelandii, pMD61 was introduced into the wild-type strain UWr. There was no apparent effect on nitrogenase activity in $\mathrm{UWr}$, while, as expected, activity was not detected in $K$. pneumoniae carrying this plasmid (Table 3 ).

The $n t r C$ plasmid pMD45 did not restore a $\mathrm{Nif}^{+}$phenotype to the regulatory mutant $A$. vinelandii $\mathrm{UW} 1 \mathrm{r}$ or prevent ammonium repression of $\mathrm{N}_{2}$ fixation in the wild-type $\mathrm{UWr}$ (Table 3). This cointegrate was stable in Azotobacter as judged by sizing the plasmid DNA on agarose gels.

\section{Expression of K. pneumoniae nif promoters in A. vinelandii}

Azotobacter species are naturally $\mathrm{Lac}^{-}$(Thompson \& Skerman, 1979) and hence no mutant construction was necessary to measure expression from nif-lac $Z$ fusions. Attempts were initially made to introduce nif:: Mudlac transcriptional fusions derived from pRD1 (Dixon et al., 1980) into $A$. vinelandii, but the resulting ampicillin resistant transconjugants were unstable, losing the plasmid during subculture. Thus it was necessary to integrate nif-lac $Z$ translational fusions constructed in vitro into wide-host-range plasmids.

The $\beta$-galactosidase activity of various $K$. pneumoniae and $A$. vinelandii strains in ammoniumsufficient and -deficient conditions are shown in Table 4. The nif L-lacZ (pMD23) and nif $F-l a c Z$ (pMD21) plasmids were both expressed in $A$. vinelandii UWr and the mutant UW $1 \mathrm{r}$ grown with or without ammonium, at levels higher than those observed in $K$. pneumoniae under any 
Table 4. $\beta$-Galactosidase activity in $A$. vinelandii and $K$. pneumoniae transconjugants with wide-host-range nif-lac fusion plasmids

$\beta$-Galactosidase activity was determined according to Miller (1972). Values are expressed in Miller units and are the means of two to four independent measurements done in duplicate, and where possible are given \pm SEM.

\begin{tabular}{|c|c|c|c|c|c|c|c|}
\hline \multirow[b]{3}{*}{ Plasmids } & \multirow[b]{3}{*}{ Fusion } & \multirow{2}{*}{\multicolumn{2}{|c|}{$\begin{array}{l}\text { K. pneumoniae } \\
\text { UNF931 }\left(\text { Nif }^{+}\right)\end{array}$}} & \multicolumn{4}{|c|}{ A. vinelandii } \\
\hline & & & & \multicolumn{2}{|c|}{ UWr $\left(\mathrm{Nif}^{+}\right)$} & \multicolumn{2}{|c|}{ UWlr $\left(\mathrm{Nif}^{-}\right)$} \\
\hline & & $-\mathrm{NH}_{4}^{+}$ & $+\mathrm{NH}_{4}^{+}$ & $-\mathrm{NH}_{4}^{+}$ & $+\mathrm{NH}_{4}^{+}$ & $-\mathrm{NH}_{4}^{+}$ & $+\mathrm{NH}_{4}^{+}$ \\
\hline pMD23 & nifL-lacZ & 808 & 27 & $\begin{array}{c}1333 \\
( \pm 300)\end{array}$ & $\begin{array}{c}2273 \\
( \pm 480)\end{array}$ & $\begin{array}{c}1934 \\
( \pm 30)\end{array}$ & $\begin{array}{c}1292 \\
( \pm 250)\end{array}$ \\
\hline pMD21 & nifF-lacZ & ND & ND & 850 & 750 & 850 & 1200 \\
\hline pMD61 & nif $H-l a c Z$ & $\begin{array}{r}2344 \\
( \pm 400)\end{array}$ & 2 & 0 & ND & 0 & 0 \\
\hline $\begin{array}{l}\text { pMD61 } \\
+ \text { pCK } 3\end{array}$ & $\begin{array}{l}\text { nifH-lac } Z \\
+\quad \text { nif } A^{\mathrm{c} *}\end{array}$ & ND & $\mathrm{ND}$ & $\begin{array}{c}17 \\
( \pm 6)\end{array}$ & $\begin{array}{c}20 \\
( \pm 2)\end{array}$ & $\begin{array}{c}26 \\
( \pm 10)\end{array}$ & $\begin{array}{c}18 \\
( \pm 2)\end{array}$ \\
\hline
\end{tabular}

conditions. A. chroococcum MCD-1 and the regulatory mutant derived from it, MCD-1008, gave similar levels of expression as judged by the chromogenic reaction on solid media containing XGal. In $K$. pneumoniae, the nif $H$, nifL and nif $F$ promoters were expressed in anaerobic conditions in the absence of ammonium, but not in its presence. In contrast, $A$. vinelandii carrying pMD61 did not express the nif $H$ promoter in Burk's sucrose medium, with or without ammonium, with $2 \mathrm{~mm}$-urea (a non-repressive nitrogen source), with $5 \mathrm{~mm}$-sodium acetate or without added molybdate, compounds known to affect nif expression in Azotobacter species (Ramos \& Robson, 1985; Premakumar et al., 1984). This lack of expression could not be attributed to plasmid instability, because when pMD61 was mobilized back into $K$. pneumoniae, lac $Z$ was again expressed in a nif-specific manner. When $K$. pneumoniae nif $A$ was introduced into $A$. vinelandii $\mathrm{UWr}$ on pCK 3 along with pMD61, expression from the $K$. pneumoniae nifH promoter was activated slightly (Table 4 ). This $\beta$-galactosidase expression was obvious after $4-7 \mathrm{~d}$ incubation of the strain on medium containing X-Gal, while the transconjugant with pMD61 alone showed no chromogenic reaction.

\section{DISCUSSION}

Expression of $l a c Z$ from pMD21 (nifF-lacZ) and pMD23 (nif L-lacZ) but not from pMD61 (nifH-lacZ) in $A$. vinelandii suggests the presence in this organism of an activator protein with similar sequence recognition properties to that of $n t r C$ from enteric organisms. This interpretation is supported by the recent isolation of a cosmid from an $A$. vinelandii library that restores an $\mathrm{NtrC}^{+}$phenotype, including $\mathrm{Nif}^{+}$, in $n t r C$ mutants of $K$. pneumoniae (A. Toukdarian, unpublished results). The failure of nif $L$ and nif $F$ fusions to be repressed by $\mathrm{NH}_{4}^{+}$in $A$. vinelandii is surprising since nitrogenase synthesis and nifHDK mRNA synthesis is prevented by $\mathrm{NH}_{4}^{+}$in this organism (Krol et al., 1982). This could indicate that the A. vinelandii activator is synthesized in the presence of high levels of $\mathrm{NH}_{4}^{+}$and repression occurs through a mechanism which fails to recognize the $K$. pneumoniae promoters. Alternatively, the $A$. vinelandii polymerase may not require a specific activator to recognize these foreign promoters, both of which show an appreciable $\mathrm{NH}_{4}^{+}$-constitutive $n$ tr $A$-independent activity in $K$. pneumoniae which is not shared by the nifH promoter (Drummond et al., 1983; Buchanan-Wollaston et al., 1981 ; ; Drummond, unpublished observations).

The question of nif-specific activation and repression is addressed by two sets of experiments presented here, utilizing the $K$. pneumoniae nif $H$ promoter fused to $l a c Z$ and the nif $L$ gene cloned on a wide-host-range vector. Repression of $\mathrm{N}_{2}$ fixation by $\mathrm{O}_{2}$ or by low levels of fixed nitrogen is 
mediated by the nif $L$ gene product in $K$. pneumoniae. A negatively acting regulatory gene may be present in Azotobacter because some $\mathrm{Nif}^{+}$revertants of the $\mathrm{Nif}^{-}$regulatory mutant UW2r are no longer repressed by $\mathrm{NH}_{4}^{+}$(Gordon \& Brill, 1972), a phenotype also shown by revertants of a $\mathrm{Nif}^{-}$ nif $L$ mutant in $K$. pneumoniae (Merrick et al., 1982; Filser et al., 1983). Also, constitutive production of nif $A$ prevents $\mathrm{O}_{2}$ repression of nif genes in both organisms (Buchanan-Wollaston et al., $1981 a$; Kennedy \& Robson, 1983). Multiple copies of wild-type nif L prevent nif expression in $K$. pneumoniae in the absence of $\mathrm{NH}_{4}^{+}$or $\mathrm{O}_{2}$, presumably by titrating out a signal molecule that communicates derepressing conditions (Buchanan-Wollaston $e t$ al., 1981 b; Riedel et al., 1983). Since the nif $L$ product apparently prevents the nif $A$ product from activating, rather than by binding directly to nif regulatory sequences (Buchanan-Wollaston \& Cannon, 1984; Drummond $\&$ Kennedy, 1984), an excess of nif $L$ in its repressive form will result in insufficient activator being present for effective expression of the other nif genes. If $A$. vinelandii has a gene functionally homologous to $K$. pneumoniae nif $L$, then one might observe an inhibitory effect of nif $L$ on a multicopy plasmid introduced to $A$. vinelandii. We find, however, that pMD1 32 had no effect on nif expression in wild-type $A$. vinelandii, although the plasmid did prevent correction of the regulatory mutant by $K$. pneumoniae nif $A$ product. The latter experiment showed that the nif $L$ product is able to function in this foreign background. Expression from the $K$. pneumoniae nifL promoter is about twofold higher in Azotobacter than in its native background (Table 4), compensating in part for the lower plasmid to chromosome ratio. Although it is possible that the $A$. vinelandii activator is too abundant to be titrated out by nif $L$ product from $\mathrm{pMD} 132$, the more likely interpretation of the negative result is that the $A$. vinelandii nif-specific activator is not affected by the $K$. pneumoniae nifL product. Also, the sequence recognition properties of the nifspecific $A$. vinelandii activator are probably different from those of the $K$. pneumoniae nif $A$ product. This is indicated by the complete lack of expression of the $K$. pneumoniae nif $H$ promoter on pMD61 in $A$. vinelandii. The low level of stimulation obtained by introducing the $K$. pneumoniae nif $A$ gene is probably due to multiple copies of nif promoters on the $A$. vinelandii chromosome which bind most of the nif $A$ product, leaving little to activate the $K$. pneumoniae nifH promoter. Multiple copies of the $A$. chroococcum nif $H$ promoter prevent full expression of nif genes in $K$. pneumoniae, indicating a strong interaction with nif $A$ product (Jones et al., 1984). However, the converse is not true: the $K$. pneumoniae nifH promoter introduced on a multicopy plasmid had no effect on nitrogenase expression in $A$. vinelandii, while similar multicopy plasmids with the $A$. chroococcum or $A$. vinelandii nif $H$ promoters greatly inhibited activity in the wild-type strain UW (Jones et al., 1984; D. Dean, unpublished observations).

Thus, nif-specific regulatory proteins in Azotobacter are likely to show interesting differences from the nif $L$ and nif $A$ products found in $K$. pneumoniae. Perhaps they reflect differences in these two organisms such as the presence in azotobacters of a second nifH gene (Premakumar et al., 1984 ; R. Robson, personal communication) and also the ability of $A$. vinelandii to fix $\mathrm{N}_{2}$ on Modeficient medium (Bishop et al., 1980). Elucidation of nif-specific control mechanisms in Azotobacter must await direct isolation of the relevant genes.

We thank Graham Saunders and Richard Humphrey for technical assistance, John Postgate and Mike Merrick for criticism of the manuscript and Beryl Scutt for typing it.

\section{REFERENCES}

Beynon, J., Cannon, M., Buchanan-Wollaston, V. \& CANNON, F. (1983). The nif promoters of Klebsiella pneumoniae have a characteristic primary structure. Cell 34, 665-671.

BISHOP, P. E. \& BRILL, W. J. (1977). Genetic analysis of Azotobacter vinelandii mutant strains unable to fix nitrogen. Journal of Bacteriology 130, 954-956.

Bishop, P. E., JARLENSKi, D. M. L. \& Hetherington, D. R. (1980). Evidence for an alternative nitrogen fixation system in Azotobacter vinelandii. Proceedings of the National Academy of Sciences of the United States of America 77, 7342-7346.

de Bruijn, F. J. \& Ausubel, F. M. (1983). The cloning and characterisation of the $g \ln F(n \operatorname{tr} A)$ gene of Klebsiella pneumoniae: role of $g \ln F(n \operatorname{tr} A)$ in the regulation of nitrogen fixation (nif) and other nitrogen assimilation genes. Molecular and General Genetics 192, 342-353.

Buchanan-Wollaston, V. \& Cannon, F. C. (1984). Regulation of nif transcription in Klebsiella pneumoniae. In Advances in Nitrogen Fixation, p. 732. Edited by C. Veeger \& W. E. Newton. The Hague: Nijhoff/Junk.

Buchanan-Wollaston, V., Cannon, M. C., Beynon, 
J. L. \& CANNON, F. C. $(1981 a)$. Role of the nif $A$ gene product in the regulation of nif expression in Klebsiella pneumoniae. Nature, London 294, 776-778.

Buchanan-Wollaston, V., Cannon, M. C. \& CanNON, F. C. $(1981 b)$. The use of cloned nif DNA to investigate transcriptional regulation of nif expression in Klebsiella pneumoniae. Molecular and General Genetics 184, 102-106.

Cannon, F. \& Postgate, J. (1983). Expression of Klebsiella nitrogen fixation genes in Azotobacter - a caution. Nature, London 306, 290.

Ditta, G., Stanfield, S., Corbin, D. \& Helinski, D. R. (1980). Broad host range DNA cloning system for gram-negative bacteria: construction of a gene bank of Rhizobium meliloti. Proceedings of the National Academy of Sciences of the United States of America 77, 7347-7351.

Dixon, R., Kennedy, C., Kondorosi, A., KrishnaPILlAI, V. \& MERRICK, M. (1977). Complementation analysis of Klebsiella pneumoniae mutants defective in nitrogen fixation. Molecular and General Genetics 157, 189-198.

Dixon, R., EAdy, R. R., Espin, G., Hill, S., Iaccarino, M., KahN, D. \& Merrick, M. (1980). Analysis of regulation of Klebsiella pneumoniae nitrogen fixation (nif) gene cluster with gene fusions. Nature, London 286, 128-132.

DRuMmond, M. \& KenNEDY, C. (1984). Use of cloned regulatory elements from $K$. pneumoniae to examine nif regulation in Azotobacter and the mode of action of the nif $L$ gene product. In Advances in Nitrogen Fixation, p. 736 . Edited by C. Veeger \& W. Newton. The Hague: Nijhoff/Junk.

Drummond, M., Clements, J., Merrick, M. \& DiXon, R. (1983). Positive control and autogenous regulation of the nifLA promoter in Klebsiella pneumoniae. Nature, London 301, 302-307.

Espin, G., Alvarez-Morales, A., Cannon, F., Dixon, R. \& MERrick, M. (1982). Cloning of the $g \ln A, n t r B$ and $n t r C$ genes of Klebsiella pneumoniae and studies of their role in regulation of the nitrogen fixation (nif) gene cluster. Molecular and General Genetics 186, 518-524.

FiguRSKI, D. H. \& HelinsKi, D. R. (1979). Replication of an origin-containing derivative of plasmid RK2 dependent on a plasmid function provided in trans. Proceedings of the National Academy of Sciences of the United States of America 76, 1648-1652.

Figurski, D. H., MeYer, R. J. \& HelinSKI, D. R. (1979). Suppression of ColEl replication properties by the IncP-1 plasmid RK2 in hybrid plasmids constructed in vitro. Journal of Molecular Biology 133 , 295-318.

Filser, M., Merrick, M. \& Cannon, F. (1983). Cloning and characterisation of nif $A$ regulation mutations from Klebsiella pneumoniae. Molecular and General Genetics 191, 485-491.

GoRdon, J. K. \& BRILL, W. J. (1972). Mutants that produce nitrogenase in the presence of ammonia. Proceedings of the National Academy of Sciences of the United States of America 69, 3501-3503.

Guerry, P., Embden, J. V. \& Falkow, S. (1974). Molecular nature of two non-conjugative plasmids carrying drug resistance genes. Journal of Bacteriology 117, 619-630.

Guterman, S. K., Roberts, G. \& Tyler, B. (1982).
Polarity in the $g \ln A$ operon : suppression of the Regphenotype by rho mutations. Journal of Bacteriology 150, 1314-1321.

Hase, T., Wakabayashi, R. N., Zumft, W. G. \& Matsubara, H. (1984). Structural homologies between the amino acid sequence of Clostridium pasteurianum $\mathrm{MoFe}$ protein and the DNA sequences of nif $D$ and $K$ genes of phylogenetically diverse bacteria. FEBS Letters 166, 39-43.

Hill, S., Kennedy, C., Kavanagh, E., Goldberg, R. B. \& HaNAU, R. (1981). Nitrogen fixation gene (nifL) involved in oxygen reputation of nitrogenase synthesis in Klebsiella pneumoniae. Nature, London 290, 424-426.

Holmes, D. S. \& Quigley, M. (1981). A rapid boiling method for the preparation of bacterial plasmids. Analytical Biochemistry 114, 193-197.

JONES, R., WOODLEY, P. \& ROBSON, R. (1984). Cloning and organisation of some genes for nitrogen fixation from Azotobacter chroococcum and their expression in Klebsiella pneumoniae. Molecular and General Genetics 197, 318-327.

KENNEDY, C. (1977). Linkage map of the nitrogen fixation (nif) genes in Klebsiella pneumoniae. Molecular and General Genetics 157, 199-204.

KenNEDy, C. \& RoBson, R. L. (1983). Activation of nif gene expression in Azotobacter by the nif $A$ gene product of Klebsiella pneumoniae. Nature, London 301, 626-628.

Kennedy, C., Cannon, F. C., Cannon, M. C., Dixon, R. A., Hill, S., Jensen, J. S., Kumar, S., McLean, P., Merrick, M. J., Robson, R. \& Postgate, J. R. (1981). Recent advances in the genetics and regulation of nitrogen fixation. In Current Perspectives in Nitrogen Fixation, pp. 146-156. Eidted by A. H. Gibson \& W. E. Newton. Canberra: Australian Academy of Science.

Krol, A. J. M., Houtelez, J. G. J., RoozendaAl, B. $\&$ VAN KAMMEN, A. (1982). On the operon structure of the nitrogenase genes of Rhizobium leguminosarum and Azotobacter vinelandii. Nucleic Acids Research 10 , 4147-4157.

MacNeil, T., MacNeil, D. \& Tyler, B. L. (1982). Fine-structure deletion map and complementation analysis of the $g \ln A-g \ln L-g \ln G$ region in Escherichia coli. Journal of Bacteriology 150, 1302-1313.

Maniatis, T., Fritsch, E. F. \& SambrooK, J. (1982). Molecular Cloning. Cold Spring Harbor, NY: Cold Spring Harbor Laboratory.

MERRICK, M. (1983). Nitrogen-control of the nif regulon in Klebsiella pneumoniae: involvement of the $n t r A$ gene and analogies between $n t r C$ and nif $A$. EMBO Journal 2, 39-44.

Merrick, M., Hill, S., Hennecke, H., Hahn, M., DIXON, R. \& KENNEDY, C. (1982). Repressor properties of the nif $L$ gene product in Klebsiella pneumoniae. Molecular and General Genetics 185, 7581.

Miller, J. H. (1972). Experiments in Molecular Genetics. Cold Spring Harbor, NY: Cold Spring Harbor Laboratory.

NaGahari, K. \& SaKaguchi, K. (1978). RSF1010 plasmid as a potentially useful vector in Pseudomonas species. Journal of Bacteriology 133, $1527-$ 1529.

Newton, J. W., Wilson, P. W. \& BurRis, R. H. 
(1953). Direct demonstration of ammonia as an intermediate in nitrogen fixation by Azotobacter. Journal of Biological Chemistry 204, 445-451.

Ow, D. W. \& Ausubel, F. M. (1983). The nif A gene which regulates the Klebsiella pneumoniae nif gene cluster can substitute for the nitrogen regulatory gene $\operatorname{gln} G$ (ntrC). Nature, London 301, 307-313.

Ow, D. W., Sundaresan, V., Rothstein, D., Brown, S. \& Ausubel, F. (1983). Promoters regulated by the $g \ln G(n t r C)$ and nif $A$ gene products share a heptameric consensus sequence in the -15 region. Proceedings of the National Academy of Sciences of the United States of America 80, 2524-2528.

Postgate, J. R. (1982). The Fundamentals of Nitrogen Fixation. Cambridge: Cambridge University Press.

Premakumar, R., Lemos, E. M. \& Bishop, P. E. (1984). Evidence for two dinitrogenase reductases under regulatory control by molybdenum in Azotobacter vinelandii. Biochimica et biophysica acta 797, 64-70.

Ramos, R. L. \& Robson, R. L. (1985). Isolation and properties of mutants of Azotobacter chroococcum defective in aerobic nitrogen fixation. Journal of General Microbiology 131, 1449-1458.

Riedel, G. E., Brown, S. E. \& Ausubel, F. M. (1983). Nitrogen fixation by Klebsiella pneumoniae is inhibited by certain multicopy hybrid nif plasmids. Journal of Bacteriology 153, 45-56.

Roberts, G. P. \& Brill, W. J. (1980). Gene product relationships of the nif regulon of Klebsiella pneumoniae. Journal of Bacteriology 144, 210-216.

Robson, R. L., Chesshyre, J. A., WheELER, C., JoNES, R., Woodley, P. R. \& Postgate, J. R. (1984).
Genome size and complexity in Azotobacter chroococcum. Journal of General Microbiology 130, 16031612.

RuvkUn, G. B. \& Ausubel, F. M. (1980). Interspecies homology of nitrogenase genes. Proceedings of the National Academy of Sciences of the United States of America 77, 191-195.

SAdoff, J. L., Shimei, B. \& Ellis, S. (1979). Characterisation of Azotobacter vinelandii deoxyribonucleic acid and folded chromosomes. Journal of Bacteriology 138, 871-877.

Shah, V. K., Davis, L. C., Gordon, J. K., OrmeJohnson, W. H. \& BRILL, W. J. (1973). Nitrogenase. III. Nitrogenase mutants of Azotobacter vinelandii: activities, cross-reactions and epr spectra. Biochimica et biophysica acta 292, 246-255.

Sundaresan, V., Ow, D. W. \& Ausubel, F. M. $(1983 a)$. Activation of Klebsiella pneumoniae and Rhizobium meliloti promoters by $g$ ln (ntr) regulatory proteins. Proceedings of the National Academy of Sciences of the United States of America 76, 61 5-619. Sundaresan, V., Jones, J. D. G., Ow, D. W. \& Ausubel, F. M. (1983b). Conservation of nitrogenase promoters from Rhizobium meliloti and Klebsiella pneumoniae. Nature, London 301, 728-731.

Szeto, W. W., Zimmerman, J. L., Sundaresan, V. \& AUSUBEL, F. M. (1984). A Rhizobium meliloti symbiotic regulatory gene. Cell 36, 1035-1043.

Thompson, J. P. \& Skerman, V. B. D. (1979). Azotobacteraceae: the Taxonomy and Ecology of the Aerobic Nitrogen-fixing Bacteria. London: Academic Press. 